Historic, Archive Document

Do not assume content reflects current scientific knowledge, policies, or practices. 



\section{“GERATY” STRAIN}

HARDY, FIELD GROWN
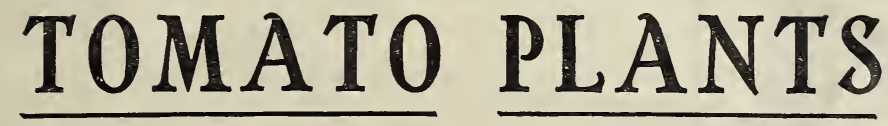

Grown from selected seed in open field and on poor soil. In infancy these plants have a hard struggle to exist-this toughens them. Poor soil causes extra exertion in root growth. The plants grow slowly and are short jointed and very hardy. They are free from disease because they are grown on fresh land each year.

When transplanted to good soil these plants grow with an astonishing rush but the tendency to short joint continues throughout the growth of the plant. As the fruit sets at the joints these plants will be much heavier fruited than frame grown plants and they will also be many days earlier.

Many of the largest canners and commercial tomato growers have been buying our plants in large quantities for many years.

We offer Spark's Earliana, Redfield Beauty, Early Detroit, Bonny Best, Greater Baltimore, Red Rock, Stone and Ponderosa.

Prices for first quality tomatoes will be high this year and the man who plants Geraty's hardy strains of plants will be certain of big profits.

Orders are now being booked for shipment from early April to July 1st. Orders must be placed well in advance, giving date shipment is wanted, as we plant only sufficient seed to insure the quantity of plants for which we have received orders. Plants cannot be held here but must be shipped when ready. If your field is not ready when plants are received you can trench them in for two weeks with no injury whatever to plants.

Terms, prices, etc., same as for cabbage plants. See page 1.

\section{Porto Rico Sweet Potato Plants}

Beyond dispute the best and most profitable sweet potato grown. A very heavy yielder requiring only minimum cultivation, as the rapid and dense growth of vines shade out srass and weeds. This potato has exceptionally fine table and keeping qualities and always finds a ready market at top prices. Orders must be placed far in advance as we only bed sufficient seed to insure the number of plants for which we have orders.

Terms, prices, etc., same as for cabbage plants. See page 1.

Tests made by the Government show that plants grown from carefully selected strains of seed, as compared with the ordinary seed, frequently produce more than double the yield of headed cabbage for the same number of plants.

Remember that in buying our plants you get the benefit of our fifty odd years of continuous seed selection, experience, integrity and financial responsibility. Wm. C. Geraty founded this business in 1868; it is now owned and managed by his sons who have worked in it since childhood, and his grandsons are now being trained to carry the business into their generation.

The purer the stock the heavier the crop and the hardier the stock the earlier the maturity. Geraty's plants have been bred, for over fifty years, to be both early and heavy yielding. 

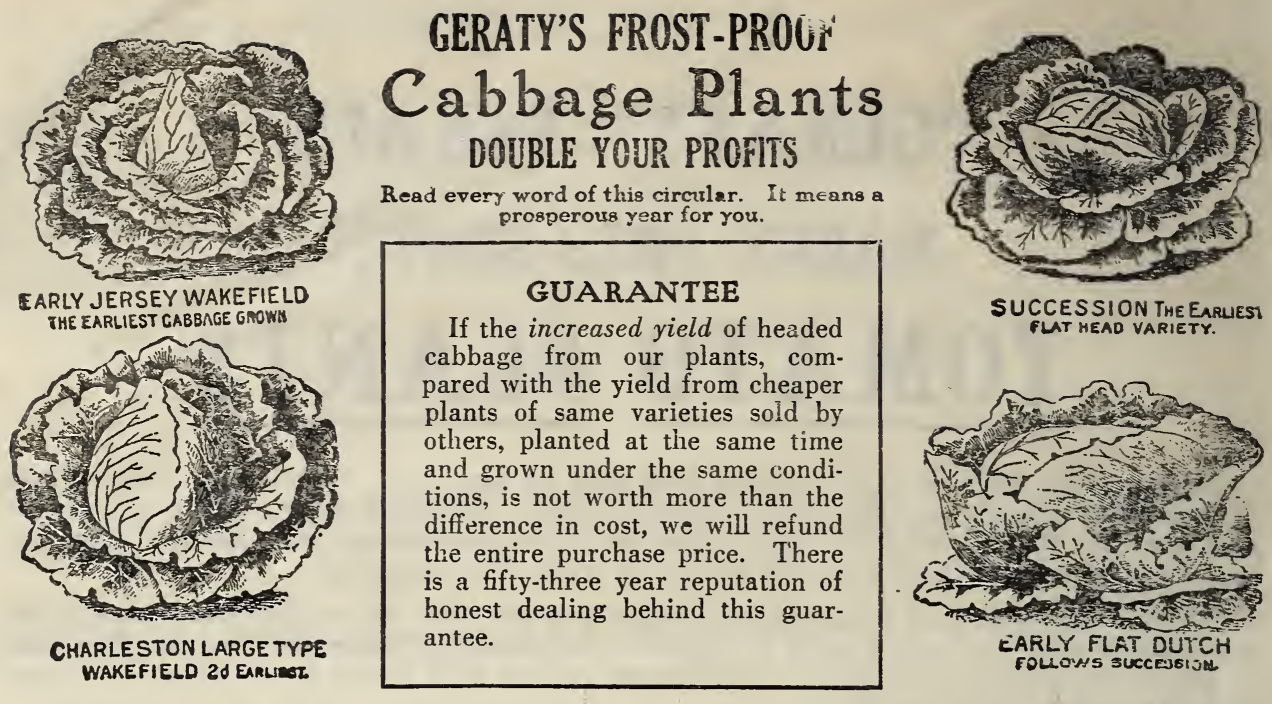

Wm. C. Geraty Co's., cabbage plants are grown on Yonges Island, off the coast of South Carolina where plants have to be tough to survive. At eight to ten weeks of age they are ready for transplanting and are guaranteed against all weather conditions down to 20 degrees above zero, although we have numberless records of our plants having survived conditions as low as 10 above zero with no injury whatever to the piants.

Geraty's plants are absolutely Frost-Proof-are grown from seed of strains which have been selected with exacting care for over fifty years. Our long years of seed selecting experience guarantees the parentage of every cabbage plant you buy from us. Absolutely no weak stock-no loss-no waste but all gain-double gain.

Compared with ordinary cabbage plants from untested and uinderb. ed parentage, our plants, in most instances, yield double the number of pounds per acr - often more.

\section{Three Weeks Earlier to Market}

Our plants should be planted a month or six weeks earlier than home grown plants. The roots will start growing at once but the tops will not start until Sping ope. S. The roots by then are established and assimilating the fertilizer and plant food and the tops will grow with a rush and headed cabbage will mature ready for market two or three weeks earlier than hot bed or coid frame plants. You know the big prices that are paid for first-on-the-market cabbage.

Be a big money maker this year-not merely a living maker. The present high freight rates coupled with the increased cost of crates, etc., will enable you to underseil shipped in cabbage in your local market and make a tremendous profit even if you sell as low as two cents a pound. Our piants should produce from six to ten tons to the acre and you can make this the most prosperous year you ever had if you act on the above suggestion.

Pay no attention to the hard, stunted and wilted appearance of plants on arrivalthey are absolutely guarantecd-set them out as soon as you receive them and be prepared for some astonicining crop results.

Four Yerieties-each one a Geraty strain with a full pedigree. Early Jersey Wakefield, Charleston Large Type Wakefield, Succession and Early Flat Dutch.

Prices by Parcel Post, postpaid: In lots of 100 to 400,50 cents per 100 ; 500 plants, all one variety, $\$ 1.75 ; 1000$ plants, all one variety, $\$ 3.25$. Plants packed only in even hundreds as follows: $100,200,300,400,500$ or 1000 of one variety to package.

Prices by Express, buyer paying delivery charges: Lots of 1000 to 4000 plants, $\$ 2.25$ per $1000 ; 5000$ and upward, $\$ 2.00$ per 1000 . For express shipments plants are packed 1000 to 2000 plants of a variety to a package. Weight per 1000 , packed for shipment, about 25 pounds. Terms cash with order. No plants shipped C.O.D.

Others are doubling their profits with Geraty's Frost-Proof, Double Crop Cabbage Plants-so can you. Act promptly. Send your order NOW so that you ma $\%$ be sure of having these money-making plants when you want them.

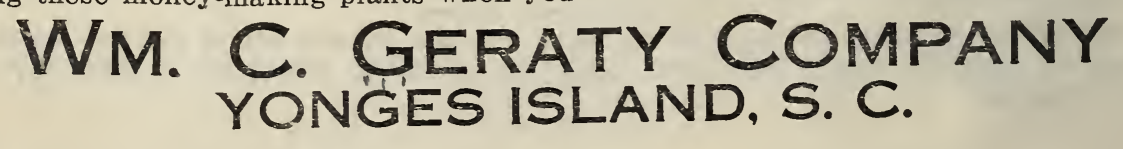

